Hovanitz, w. 1944. Genetic data on the two races of Colias chrysotheme in North America and on a white form occurring in each. Genetics, 29, 1-30.

JAE, R. J. 1972. Natural inter-breeding of close nymphalid groups. 7. Lepid. Soc., 26, 28. xozhler, P. 1927. Biologia de Chlosyne Saundersi Dbl. \& Hew. Rev. Soc. Ent. Argentina, 1-2 (5), 3-4.

LANG, A. 1904. Uber voversuche zu untersuchungen uber die varietätenbilding von Helix hortensis Müller und Helix nemoralis L. Denkschr. Med. Natuurw. Ges. Fena, 11, 439-506.

LANG, A. 1906. Úber die bastarde von Helix hortensis Müller und Helix nemoralis L. Festschr. Jena, $1-120$.

MAYR, E. 1963. Animal Species and Evolution. Belknap Press, Cambridge, Mass., U.S.A.

NECK, R. w. 1973. Foodplant ecology of the butterfly Chlosyne lacinia (Geyer) (Nymphalidae). I. Larval foodplants. 7. Lepid. Soc., 27, 22-33.

NEGK, R. W., BUSH, G. L., AND DRUMMOND, B. A. III. 1971. Epistasis, associated lethals and brood effect in larval colour polymorphism of the patch butterfly, Chlosyne lacinia. Heredity, 26, 73-84.

PRIESTAFr, R. G. 1970. Courtship and mating between Chlosyne neumoegeni and Chlosyne califormica (Nymphalidae). F. Lepid. Soc., 24, 226.

PYBURN, w. F. 1961. The inheritance and distribution of vertebral stripe colour in the cricket frog. In Vertebrate Speciation, edited by W. F. Balir. University of Texas Press, Austin, Texas, U.S.A.

SINNOTT, E. W., AND DURHAM, G. B. 1922. Inheritance in the summer squash. F. Heredity, 13, 177-186.

sturtevant, A. H. 1929. The genetics of Drosophila simulans. Camegie Inst. Wash. Publ., 399, $1-62$.

\title{
A NEW DOMINANT SPOTTING AND SILVERING FACTOR IN THE GUINEA-PIG
}

\author{
CATHERINE WHITEWAY \\ Langley Cottoge, Lower Longley, Wiveliscombe, Tounton
}

Received 26.i.73

Spotring in the guinea-pig was investigated by Castle (1912), Ibsen (1916), Wright (1917, 1920, 1923), Eaton (1928), Wright and Chase (1936) and Chase (1939). Silvering was studied by Ibsen (1932), Lambert (1935) and Wright $(1947,1959 a, b)$. The current view of both silvering and spotting has been summarised by Searle (1968). The major white-spotting factor is the incompletely recessive gene $s$, and the existence of minor spotting factors is suspected. Guinea-pigs homozygous for $s$ show varying degrees of spotting, often of the "Dutch" pattern with white blaze, collar and feet. Heterozygotes may show some white, especially on the face or feet. The incompletely recessive gene si produces an intermingling of white hairs among coloured ones in the homozygote, and again its effect is variable. Some individuals may have a few white hairs on the belly while others are nearly white. Both factors are apparent at birth; neither is progressive and neither has an effect on eye colour.

Silvering and spotting are also produced by the combination of brindle $e^{p}$ with the lower alleles in the $C$ dilution series (Wright, 1947). An incompletely recessive factor for progressive silvering was reported by Lambert. This does not manifest itself until the animal is between 3 and 4 months old. A fourth silvering gene, mentioned by Wright, produces dinginess in the coat of dark-eyed non-dilute browns $b b C-P-$. Ibsen (1932) noted a similar action on brown $(b b)$ and black $(B)$ hairs, which he attributed to an incom- 
pletely dominant factor $W$. Ibsen proposed the symbol Ro for the incompletely dominant silvering he had observed, but did not mention eye colour. Wright (1947) examined Ibsen's and Pictet and Ferrero's (1940) findings and concluded that the silvering in both cases was caused by $s i$.

In February 1972 the author purchased a pair of guinea-pigs from a fancier, Miss E. Wilson of Scarborough. The male was black, unevenly silvered with white hairs on back, sides and belly, with black head, white blaze, black feet (one white spotted) and dark red eyes. It was described as a Blue Roan. The female was self-black, in pig to another blue roan. On 19th April she had a litter of three, two blacks and a blue roan very similar in appearance to the male described above. Unfortunately, this animal died shortly after birth.

At this stage it was assumed that the blue roan was homozygous for a recessive silvering factor, probably one already known, and the black heterozygous for this factor. Neither the spotting nor the eye colour had been mentioned in the literature in connection with any recessive silvering, however. The seller's description of the breeding procedure and expectations were consistent with this theory of a recessive factor. A blue roan-black mating was expected to produce blue roans and blacks in the proportion I: 1. A roan $\times$ roan mating was understood to produce roans with too much white to appeal to the fancier, but explicit information on this point has not been forthcoming. The original appearance of the new colour in a closed colony of self-black guinea-pigs has been described (Wilson, 1969) as a totally unexpected event.

In the meantime the blue roan male of the purchased pair was mated to a self brown, $a a b b C-E$-, bred from non-spotted and non-silvered stock. A litter of three was born on 1st November. One was an entirely black female with black eyes. Another female was heavily silvered, almost white, with silvered black feet and cheek patches, and dark red eyes. The male was similarly marked but with more heavily silvered head and feet, and he too had dark red eyes. White spotting was present in both these youngsters, in the form of a blaze and patches on the hind feet.

If the male parent had been homozygous for a recessive silvering factor, the litter would have been made up entirely of self-blacks. In the light of the event described, it is suggested that the blue roan male is heterozygous for a new dominant spotting and silvering gene, for which the symbol $R s$ is proposed. The recessive allele is apparently self, $r s$. It is hoped that the new factor will be further investigated.

\section{REFERENCES}

CASTLE, w. E. 1912. On the inheritance of tricolor coat in guinea pigs and its relation to Galton's law of ancestral heredity. Amer. Nat., 46, 437-440.

CHASE, н. в. 1939. Studies on the tricolor pattern of guinea pigs. 1. the relation between different areas of the coat in respect to the presence of color. Genetics, 24, 610-621.

zaton, O. N. 1928. The occurrence of nose spots and tail spots in guinea pigs. 7 . Agric. Res., 37, 25-41.

IBSEN, H. L. 1916. Tricolor inheritance. 1. Tricolor series in guinea pigs. Genetics, 1, $287-$ 309.

IBSEN, H. L. 1932. Modifying factors in guinea pigs. Proc. 6th Int. Congress Genetics, 2, 97-101. LAMBERT, w. v. 1935. Silver guinea pigs. F. Hered., 26, 279-283.

PICTET, A., AND FERRero, A. 1940. Recherches sur l'hérédité de la dilution et du blanchiment du pelage dans le génie Cavia. Genetica, 22, 1-22. 
SEARLE, A. G. 1968. Comparative Genetics of Coat Colour in Mammals. Logos Press (distrib. Academic Press), London.

wILson, z. 1969. Don't rely on a freak to achieve a standard-but it can happen. Fur and Feather, 132, 1066.

WRIGHT, s. 1917. Color inheritance in mammals. 5. The guinea pig. F. Hered., 8, 476480 .

WRIOHT, s. 1920. The relative importance of heredity and environment in determining the piebald pattern of guinea pigs. Proc. Nat. Acad. Sci., 6, 320-332.

WRIGHT, s. 1923. The relation between piebald and tortoiseshell color patterns in guinea pigs. Anat. Rec., 26, 393.

WRIGHT, s., AND CHASE, H. B. 1936. On the genetics of the spotted pattern of the guinea pig. Genetics, 21, 758-787.

WRIGHT, s. 1947. On the genetics of several types of silvering in the guinea pig. Genetics, $32,115-141$.

WRIGHT, s. 1959a. On the genetics of silvering in the guinea pig with special reference to interaction and linkage. Genetics, 44, 387-405.

WRIGHT, s. 1959b. Silvering (si) and diminution $(d m)$ of coat color of the guinea pig and male sterility of the white or near white combination of these. Genetics, 44, 563-590. 